\title{
Abuse of Law in the Context of European Insolvency Law
}

\author{
by \\ Horst EIDENMÜLleR*
}

Abuse of law is a concept that can be found in the private laws of many jurisdictions in the world. The European Court of Justice has recently resorted to the concept quite often when dealing with the reach of the fundamental freedoms guaranteed by the EC Treaty. This article applies the abuse of law concept to European insolvency law questions. Of central importance here are the rules determining jurisdiction to open main insolvency proceedings under the European Insolvency Regulation (EIR). Such jurisdiction is tied to a debtor's 'Centre of Main Interests' (COMI) which can be changed - abusively. The article starts by exploring the context of the debate on abuse of law with respect to European insolvency law. It is characterised by regulatory competition between the Member States. The general elements of the abuse of law concept are then presented. It is an interpretative concept that looks at the dominant purpose of a particular legal provision. The article explores this concept with respect to potential abuses of freedom of establishment on the one hand and the EIR on the other hand in an insolvency context. Its main thesis is that COMI shifts that evidently do not contribute to maximising the debtor's net assets are abusive. COMI shifts that evidently benefit the debtor at the expense of its creditors or some creditors at the expense of others fall into this category: they are driven by distributive rather than by efficiency concerns. The article concludes with a proposal to amend the EIR such that reliance on the abuse of law concept to prevent opportunistic COMI shifts would be less pressing.

Table of Contents

ECFR 2009, 1-28

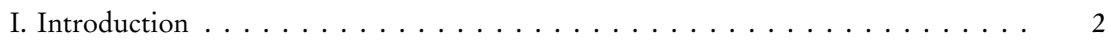

II. The Context of the Debate in Insolvency Law . . . . . . . . . . . . . . 4

* Professor Dr Horst Eidenmüller, LLM (Cantab), holds the chair for Private Law, German, European, and International Company Law at the Ludwig Maximilians University in Munich (Research Professorship). In the academic year 2008/2009, he is a Fellow of the Institute for Advanced Study in Berlin. I should like to thank John Armour, Andreas Engert, Heribert Hirte and an anonymous reviewer for helpful comments on an earlier draft and Tilman Turck for excellent research assistance. 


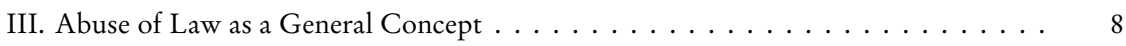

IV. Abusing Freedom of Establishment . . . . . . . . . . . . . . . . . . . . . . . . . 11

1. Abusing Freedom of Establishment by COMI Shifts . . . . . . . . . . . . . . . . . . . 11

2. Free Choice of the Applicable Insolvency Regime . . . . . . . . . . . . . . . 12

V. Abusing the European Insolvency Regulation . . . . . . . . . . . . . . . . . . . . . . . . 13

1. Goals of the Regulation and Prerequisites for Abuse . . . . . . . . . . . . . . . . . . 14

2. COMI Shifts Before the Insolvency Petition . . . . . . . . . . . . . . . . . . . . 16

3. COMI Shifts After the Insolvency Petition . . . . . . . . . . . . . . . . . . . . . 20

4. Abuse by Member States / Courts . . . . . . . . . . . . . . . 22

VI. Reforming the European Insolvency Regulation . . . . . . . . . . . . . . . . . . . 24

VII. Summary and Conclusion . . . . . . . . . . . . . . . . . . . . 26

\section{Introduction}

Questions of abuse of law have gained increasing importance in the case law of the European Court of Justice (ECJ). ${ }^{1}$ From a business law perspective, the Centros jurisprudence of the Court stands out in particular (cases Centros, Überseering and Inspire Art). ${ }^{2}$ With this jurisprudence, the door has been opened for free choice of the applicable company law regime and regulatory competition in the area of company law in Europe. At the same time, the ECJ has made it very clear that the national courts may, on a case by case basis, take abuse or fraudulent conduct into account when assessing the reach of freedom of establishment. ${ }^{3}$ Hence, Member States may apply their own national law to a company established in another Member State if this ensures that abusive behaviour is kept in check. However, the mere fact that a company has no real connection to the Member State in which it was established apart from its registered office does not, in the Court's opinion, constitute abuse. ${ }^{4}$

Whereas in the field of company law, pioneering developments are associated with the ECJ's interpretation of the fundamental freedoms of the EC Treaty, it is a statute that has in the past dominated legal practise and academic

1 For a discussion of the case law see H Eidenmüller (ed), Ausländische Kapitalgesellschaften im deutschen Recht (München: Verlag C.H. Beck, 2004), $\$ 3$ notes 73 et seq.

2 Case C-212/97 Centros v Erbvervs- og Selskabsstyreisen [1999] ECR I-01459; Case C208/00 Überseering v Nordic Construction Company Baumanagement GmbH (NCC) [2002] ECR I-09919; Case C-167/01 Kamer van Koophandel en Fabrieken voor Amsterdam v Inspire Art Ltd. [2003] ECR I-10155. The Court's judgment on 16 December 2008 in the Cartesio case (CARTESIO Oktató és Szolgáltató bt, Case C-210/ 06 [yet unpublished]) has not affected its Centros jurisprudence. In contrast to this jurisprudence, it dealt with a an outward bound shift of a company's real seat. Moreover, the Court did not address abuse of law issues in Cartesio.

3 Centros (n 2) para 25.

4 Centros (n 2) para 26; Inspire Art (n 2) para 139. 
discourse in the field of insolvency law and continues to do so: the European Insolvency Regulation (EIR), ${ }^{5}$ which entered into force on 31 May 2002. Its main objective is to provide a stable framework for the conduct of crossborder insolvency proceedings in Europe. To achieve this objective, the EIR contains rules on jurisdiction for insolvency proceedings, the recognition of decisions with respect to such proceedings, and the coordination of multiple proceedings involving a single debtor. The ECJ has meanwhile handed down two judgments on the EIR: the Susanne Staubitz-Schreiber case was decided on 17 January $2006^{6}$ and the Eurofood case on 2 May 2006. Both cases concern jurisdictional issues arising under the regulation, questions of forum shopping and, as a consequence, are also relevant to abuse of law issues. However, until now there is no ECJ judgment specifically dealing with abuse of law in the context of insolvency law.

This is the background against which the following article looks at abuse of law as a concept in the insolvency law field. The goals of the article are twofold. First, I would like to offer a roadmap to the ECJ that could guide the Court when having to decide an abuse of law case in the area of insolvency law. Hence, I am not so much interested in making sense of the existing ECJ jurisprudence with respect to abuse of law in other fields or in interpreting or clarifying this jurisprudence. I rather aim to sketch the outlines of an appropriate abuse of law concept with a focus on insolvency law questions. Second, I would like to explore a potential reform of the EIR that would spare the ECJ the difficult task of developing a detailed abuse of law concept designed to apply to insolvency law questions. Could the EIR be changed in a way that would make abuse of law as a concept superfluous or at least less important?

The article is divided into six sections. In Section II, I will lay out the context of the debate on abuse of law in the field of insolvency law. Section III will deal with abuse of law as a general doctrinal concept. Section IV will be on abusing freedom of establishment (primary community legislation) with respect to insolvency issues, and in Section V, I will discuss abuse of the EIR (secondary community legislation). Section VI will present a proposal to amend the EIR to decrease its susceptibility for potential abuse. Section VII summarises the article's main results and offers a conclusion. The main focus of the article will be on companies and not on natural persons. Abuse of law issues in the field of insolvency law are not limited to the former, though. Hence, Sections V and

5 Council Regulation (EC) 1346/2000 of 29 May 2000 on insolvency proceedings, [2000] OJ L 160/1.

6 Case C-1/04 Susanne Staubitz-Schreiber [2006] ECR I-701.

7 Case C-341/04 Eurofood IFSC Ltd [2006] ECR I-3813. 
VI will also be examining abuse of law questions associated with the insolvency of natural persons.

\section{The Context of the Debate in Insolvency Law}

Abuse of law issues with respect to European insolvency law are closely linked to questions of jurisdiction arising under the EIR, forum shopping and regulatory competition. The EIR ties jurisdiction for main insolvency proceedings to a debtor's 'Centre of Main Interests' (COMI), Art 3 para 1 EIR. There is a refutable presumption stating that the COMI of a company or legal person conforms to its registered office. The COMI was chosen as a criterion because it was considered advantageous to execute main insolvency proceedings at a location to which the creditors are accustomed, where they lived, transacted with the debtor and where most of the debtor's assets are located - generally speaking: at a place where "the business was done". ${ }^{8}$ The great importance of the COMI concept stems from the fact that insolvency proceedings are subject to the rules of the forum in which they are opened, Art 4 EIR. If, e.g., main insolvency proceedings over the assets of a German company are opened in England, these proceedings are governed by English insolvency law.

Since the early days of the EIR, the COMI concept occupied centre stage with respect to practical importance and scholarly debate. ${ }^{9} \mathrm{COMI}$ is a fact-sensitive criterion, and the facts can be changed or manipulated. It took some time until the ECJ received an opportunity to clarify some issues surrounding the use of the COMI concept. In its Eurofood decision, the ECJ held: "The scope of that concept is highlighted by the 13 th recital ..., which states that 'the "centre of main interests' should correspond to the place where the debtor conducts the administration of his interests on a regular basis and is therefore ascertainable by third parties'. That definition shows that the centre of main interests must be identified by reference to criteria that are both objective and ascertainable by third parties. That ... [is] necessary in order to ensure legal certainty and

8 See M Virgòs and E Schmit, "Report on the Covention on Insolvency Proceedings", para 75, e. g. published as annex 2 to G Moss, IF Fletcher and S Isaacs (eds), The EC Regulation on Insolvency Proceedings: A Commentary and Annotated Guide (Oxford: Oxford University Press, 2002).

9 See B Wessels, "The Place of the Registered Office of a Company: a Cornerstone in the Application of the EC Insolvency Regulation”, (2006) 3 European Company Law 183; Pannen (ed), European Insolvency Regulation (Berlin: de Gruyter, 2007), Art 3 notes 15 et seq. 
foreseeability concerning the determination of the court with jurisdiction to open main insolvency proceedings.” 10

The Court's emphasis on ascertainability, certainty and foreseeability is clearly driven by the desire to restrict forum shopping and regulatory competition in bankruptcy law. Nevertheless: even "objective and ascertainable" facts can be changed and/or manipulated, and it appears that the intensity of forum shopping has not decreased after the Eurofood decision. ${ }^{11}$ The United Kingdom in particular has established itself as a popular venue for the restructuring of failing enterprises, apparently because of the attractive features of the 'Company Voluntary Arrangement' procedure. ${ }^{12}$ Cases such as DNick Holding plc and Schefenacker plc, in which big German companies were first transformed into English ones and then restructured in London, are not rare exceptions. A rising number of companies in distress, their creditors and advisors seem to have a different view on forum shopping from that of the ECJ. Is forum shopping and regulatory competition in insolvency law in Europe a problem?

From an economic point of view, the answer to this question depends on goals that (international) insolvency rules are supposed to achieve. ${ }^{13}$ I submit that three such objectives are important. First, insolvency law rules should strive to maximise the net assets available to satisfy the creditors' claims. A firm should be liquidated only if its liquidation value is greater than its reorganisation value. Reorganisation procedures should be designed so that this filtering function is correctly performed. ${ }^{14} \mathrm{~A}$ corollary of the aim to maximise the net assets available to satisfy creditors' claims is that bankruptcy costs should be minimised. Procedures should be as speedy and simple as possible. Discrepancies between the applicable insolvency and company law should be avoided. Such discrepancies create frictions in the insolvency administration and these translate into costs. Second, insolvency rules should contribute to fostering the efficiency of credit contracts. This efficiency is primarily a function of the correct pricing of credit risk. Of crucial importance here is the foreseeability of the bankruptcy forum and the applicable bankruptcy law. Hence, in

10 Eurofood (n 7) paras 32-33.

11 See the cases discussed in Sections III-V of this article.

12 For details about the new CVA see IF Fletcher, "UK Corporate Rescue: Recent Developments - Changes to Administrative Receivership, Administration, and Company Voluntary Arrangements - The Insolvency Act 2000, The White Paper 2001, and the Enterprise Act 2002", (2004) 5 European Business Organization Law Review 119, 130 et seq.

13 On these issues see H Eidenmüller, "Free Choice in International Company Insolvency Law in Europe”, (2005) 6 European Business Organization Law Review 423, 429 et seq.

14 On this issue see H Eidenmüller, Unternehmenssanierung zwischen Markt und Gesetz (Cologne: Verlag Dr. Otto Schmidt, 1999), pp. 31 et seq. 
emphasising the "legal certainty and foreseeability" of the bankruptcy forum, the ECJ stresses a point that is of special economic relevance. Third, insolvency rules should strive to protect involuntary and other "nonadjusting" creditors. ${ }^{15}$ Involuntary creditors such as tort creditors do not bargain for a claim and hence cannot protect themselves. "Non-adjusting" creditors are creditors that, in principle, could bargain for protection but fail to do so because they lack the skills, the information, or other resources, or who abstain from self-protection because they consider it to be uneconomical to invest resources to achieve that aim, e. g. because they only have very small claims.

How does the COMI concept of the EIR fare against these criteria? On a theoretical level, arguments can be advanced both for positive and negative effects. On the one hand, the available reorganisation procedures in the UK may be particularly efficient and speedy, attracting failing companies who seek fast and economical restructuring. On the other hand, forum shopping on the eve of bankruptcy also causes some serious problems: discrepancies between the applicable company and insolvency law trigger (additional) bankruptcy costs (think of English insolvency proceedings over the assets of a German company), risk-inadequate credit contracts might be concluded and non-adjusting creditors exploited. ${ }^{16 / 17}$ Empirical evidence on the overall

15 The term "non-adjusting" creditors has been introduced in the literature by Bebchuk and Fried. See L Bebchuk and J Fried, "The Uneasy Case for the Priority of Secured Claims in Bankruptcy”, (1996) 105 Yale Law Journal 857, 882 et seq; L Bebchuk and J Fried, "The Uneasy Case for the Priority of Secured Claims in Bankruptcy: Further Thoughts and a Reply to Critics", (1997) 82 Cornell Law Review 1279, 1295 et seq.

16 It surely is debatable whether the exploitation of involuntary or other "non-adjusting" creditors is a big risk/problem empirically in the European context. The possibility to initiate territorial insolvency proceedings in particular (Art 3 paras 2-4 EIR) and the relevance of the law governing an employment contract also for insolvency issues (Art 10 EIR) seem to afford some protection. However, the former protection depends on an establishment being retained in the Member State of the "old" COMI. In any event, the theoretical exploitation risk exists, and no studies have been undertaken yet to measure it empirically.

17 All in all, I believe that W-G Ringe, "Forum Shopping under the EU Insolvency Regulation" (August 1, 2008), http://ssrn.com/abstract=1209822, p. 18, underestimates the problems of forum shopping associated with the COMI standard. He writes: "A company's migration does not necessarily have to take place in the vicinity of insolvency. I would argue therefore that a creditor is never able to predict which insolvency law his claim will be subject to - as long as the Internal Market consists of different substantive insolvency regimes. At the least, it is the creditor's responsibility to take protection against this type of risk as it is against every other type of business risk.” To be sure, COMI changes do occur also in the normal course of business. But opportunistic COMI changes on the eve of bankruptcy aggravate the problem: creditors expect the worst, and that may have very bad consequences for credit markets. 
economic effects of insolvency forum shopping in Europe is missing. There are studies on bank recovery rates suggesting that these are high in the UK, lower in Germany, and even lower in France. ${ }^{18}$ However, these findings only tell us something about how banks fare in English insolvency proceedings, and they are not helpful for assessing the overall net assets available to satisfy creditors' claims. Even more importantly, the effects of forum shopping on credit contracts and credit markets are not reflected in these results.

The situation in Europe is to some extent comparable to the situation in the United States where bankruptcy forum shopping has been around for many years. ${ }^{19}$ Delaware was the preferred bankruptcy venue until the end of the twentieth century when New York took over. Firms reorganised in Delaware show higher refiling rates than firms reorganised elsewhere (which is bad), ${ }^{20}$ but Delaware proceedings are faster than other proceedings (which is good).$^{21}$ Hence, the available empirical evidence from the United States with respect to bankruptcy forum shopping is mixed.

To conclude: the context of the debate on abuse of law in the insolvency field in Europe is characterised by forum shopping and regulatory competition with unclear overall economic effects. No conclusive empirical data exists on the total efficiency effects of forum shopping in the insolvency field. Both positive and negative consequences can be identified on a theoretical level, but the evidence to pass a final judgment on the phenomenon is lacking.

18 Cf S Davydenko and J Franks, "Do Bankruptcy Codes Matter? A Study of Defaults in France, Germany and the UK" (September 2006), http://ssrn.com/abstract $=647861$.

19 For an influential monograph on the topic see LM LoPucki, Courting Failure (Michigan: The University of Michigan Press, 2005).

20 LM LoPucki and SD Kalin, "The Failure of Public Company Bankruptcies in Delaware and New York: Empirical Evidence of a 'Race to the Bottom'”, (2001) 54 Vanderbilt Law Review 231; LM LoPucki and JW Doherty, "Why are Delaware and New York Bankruptcy Reorganizations Failing?”, (2002) 55 Vanderbilt Law Review 1933.

21 KM Ayotte and DA Skeel, "Why Do Distressed Companies Choose Delaware? An Empirical Analysis of Venue Choice in Bankruptcy", (2003) University of Pennsylvania Law School: Scholarship at Penn Law, Paper 20; RK Rasmussen and RS Thomas, "Whither the Race? A Comment on the Effects of the Delawarization of Corporate Reorganizations”, (2001) 54 Vanderbilt Law Review 283, 295 et seq. 


\section{Abuse of Law as a General Concept}

As already mentioned in the beginning of this article, the ECJ has recently handed down a series of judgments that are particularly important with respect to the issue of abuse of law as a general doctrinal concept. ${ }^{22}$ In European company law there are the cases Centros, Überseering and Inspire $A r t,{ }^{23}$ and in European tax law there are the cases Halifax and Cadbury Schweppes. ${ }^{24}$ As mentioned above, the cases Susanne Staubitz-Schreiber and Eurofood in the insolvency law field touch issues bordering on abuse of law questions, but they do not discuss the concept directly.

If one wishes to explore whether abuse of law is a general (European) legal concept and what the elements of this concept are, the existing case law of the ECJ is of only limited help. The Court must decide case by case. Moreover, its case law is characterised by the attempt to do justice to various fact patterns that arise in different areas of the law and are relevant for different fundamental freedoms. These circumstances are not conducive to developing an abuse of law concept "top down" and in a general fashion. Hence, it comes as no surprise that the ECJ's jurisprudence on abuse of law poses more questions than it provides clear-cut answers. First, the Court is unclear about the basis (the "location") of the concept: does it derive from European law? Or is it a concept of the Member States' laws? Second, there is no clear distinction drawn between abuse of law and fraud. In many cases, the ECJ seems to confuse the two concepts. ${ }^{25}$ Third, the ECJ is unclear on whether a subjective element is necessary for abuse of law to be ascertained, and if so, what sort of subjective element is required. Fourth and finally, the Court does not spell out precisely the consequences of abuse, once it has been ascertained. In the Centros judgment, for example, the ECJ held that Member States are justified in preventing abuse by "denying" someone the benefit of the

22 On the question whether it even constitutes a general principle of EC law, see R de la Feria, "Prohibition of Abuse of (Community) Law: The Creation of a New General Principle of EC Law Through Tax", (2008) 45 Common Market Law Review 395, 436 et seq.

23 See n 2. Further, there are the "older" cases Pafitis, Kefalas and Diamantis on the second directive: Case C-441/93 Panagis Pafitis v Trapeza Kentrikis Ellados AE [1996] ECR I1347; Case C-367/96 Alexandros Kefalas and Others $v$ Elliniko Dimosio and Organismos Ikonomikis Anasygkrotisis Epicheiriseon AE (OAE) [1998] ECR I-2843; Case C-373/97 Dionysios Diamantis v Elliniko Dimosio, Organismos Ikonomikis Anasygkrotisis Epicheiriseon AE (OAE) [2000] ECR I-1705.

24 Case C-255/02 Halifax plc, Leeds Permanent Development Services Ltd and County Wide property Investments Ltd $v$ Commissioners of Customs E Excise [2006] ECR I1609 paras 68 et seq; Case C-196/04 Cadbury Schweppes, OLC v. Commissioners of Inland Revenue [2006] ECR-I-7995 paras 55 et seq.

25 See, e.g. Centros (n 2) paras 24-25. 
provisions of Community law on which he or she seeks to rely. ${ }^{26}$ What does this mean exactly?

Hence, it is advisable to keep some distance from the ECJ jurisprudence when thinking about abuse of law as a general European legal concept. To begin with, the distinction between abuse of law and fraud is critical. Abuse of law is about correctly applying the law to a specific set of facts, whereas fraud is about correctly determining the facts to which the law then is applied. ${ }^{27}$ For instance, the Brochier cases that were litigated in European courts in recent years were fraud cases and not abuse of law cases. ${ }^{28}$ Brochier was an English limited company that clearly had its COMI in Nuremberg in Germany. However, an initial petition was made for the opening of main insolvency proceedings in London. That petition was supported by a distorted set of facts presented to the High Court. ${ }^{29}$ The facts were twisted to create the impression that Brochier's actual head office was in London, whereas on an undistorted and complete set of facts there could be no doubt that the company's COMI was in fact in Nuremberg.

With respect to the elements of the abuse of law concept, there should be two requirements. First, there is only an abuse of law if the law is used according to its formal wording but contrary to its purpose. ${ }^{30}$ This implies that abuse of law in essence is about the proper interpretation of a particular legal provision. Such a proper interpretation does not stick to the wording of a rule but also takes into account its rationale. Abuse of law, therefore, is an interpretative

26 Centros (n 2) paras 24-25.

27 This is also emphasised by H Fleischer, "Der Rechtsmissbrauch zwischen Gemeineuropäischem Privatrecht und Gemeinschaftsprivatrecht”, (2003) Juristenzeitung 865, 870. Contrast A Kjellgren, "On the Border of Abuse - The Jurisprudence of The European Court of Justice on Circumvention, Fraud and Other Misuses of Community Law”, (2000) European Business Law Review 179, 180, who maintains that fraud can be conceived a special form of abuse.

28 Hans Brochier Holdings Ltd v Exner [2006] EWHC 2594; Hans Brochier Holdings Ltd $v$ Exner, High Court of Justice London, Order of 8 December 2006 (5618/06), [2007] Neue Zeitschrift für das Recht der Insolvenz und Sanierung 187; Local Court (“Amtsgericht”) Nuremberg, Resolution of 15 August 2006 (8004 IN 1326-1331/06), [2007] Zeitschrift für Wirtschaftsrecht 81; Local Court (“Amtsgericht”) Nuremberg, Resolution of 1 October 2006 (8034 IN 1326/06), [2007] Zeitschrift für Wirtschaftsrecht 83.

29 Hans Brochier Holdings Ltd v Exner [2006] EWHC 2594.

30 This is also stressed by W Schön, "Abuse of rights and European tax law”, in: JA Jones, P Harris and D Oliver (eds), Comparative Perspectives on Revenue Law - essays in honour of John Tiley (Cambridge: Cambridge University Press, 2008), p. 75, pp. 79 et seq. If the main purpose of a particular rule is to achieve legal certainty, then one has to look at other (secondary) purposes and ask the question whether the person relying on a particular legal position does so in contradiction of these purposes. 
concept, not a self-standing principle that is independent from the purpose of the provision in question. ${ }^{31}$ Second, abuse of law requires that the meeting of the formal requirements of a provision goes back to a deliberate action of the user. There must be some manufacturing of the facts - as opposed to the deception about facts - for an abuse of law to arise. What is not necessary, though, is a specific "abuse intention" of the user, i.e., it is not necessary that the user has deliberately or at least knowingly used the law for a purpose which it has (objectively) not been intended to serve. All that is required is that the user establishes the formal elements of a legal provision and objectively makes use of it for a purpose that does not conform to its rationale.

The interpretative character of the abuse of law concept has a bearing on the question whether the concept is part of EC law or part of the laws of the Member States. The answer to this question depends on the particular legal provision that has allegedly been abused. If abuse of EC law is the issue, the concept must be a European one. Conversely, if abuse of a legal provision of a Member State is the issue, the concept belongs to the law of that Member State. However, the EC and the national level are interrelated when it comes to community directives. Technically speaking, the abuse of a legal provision of a Member State implementing a particular provision in a community directive is a question of the law of that Member State. In assessing the purpose of the legal provision in question, however, the directive and its purpose may come into play: national laws implementing community directives must be interpreted in conformity with the purpose(s) of the directive. ${ }^{32}$

Finally, abuse of law is in principle not restricted to subjective entitlements ("claims") and private actors. The scope of the concept is broader. Although most of the relevant cases will centre around subjective entitlements being abused by private actors, there might be cases where other types of legal provisions are abused and where it is not a private actor but a public entity that engages in abusive conduct. Those cases are not only conceptually conceivable, they are, as we will see, potentially relevant especially in the field of insolvency law.

Summing up the discussion on abuse of law as a general concept, we can conclude that it is an interpretative concept on the scope of a particular legal provision. Its two main elements are (i) use of law contrary to its purpose and (ii) a deliberate action of the user in the establishment of the formal requirements of the provision in question. A specific "abuse intention" is not

31 See A Teichmann, Die Gesetzesumgehung (Göttingen: Verlag Otto Schwartz \& Co, 1962), pp. 64 et seq et passim. However, Teichmann maintains that there are very few cases that cannot be solved by interpretation.

32 See in general W Brechmann, Die richtlinienkonforme Auslegung (München: Verlag C.H. Beck, 1996). 
required. Insofar as abuse of European law is the issue, the abuse of law concept is necessarily a European concept.

\section{Abusing Freedom of Establishment}

It has already been emphasised that in the insolvency field, both freedom of establishment (Arts 43 and 48 EC Treaty) and the EIR play a critical role with respect to abuse of law issues. Also, as we have just noted, abuse of law is an interpretative concept at the heart of which lies the purpose of a particular legal provision. Hence, it is sensible to address abuse of law questions with respect to freedom of establishment on the one hand and the EIR on the other hand separately. In this section of the article, I will consider the former, while the next section will discuss the latter.

In the field of company law, two crucial questions arise with respect to the influence of Arts 43 and 48 EC Treaty on the choice set of entrepreneurs: one can ask whether setting up a company in another Member State without there being any further connections to it apart from the company's registered office constitutes an abuse of freedom of establishment (the "Centros question"); a connected question is whether freedom of establishment forces the Member States to recognise a "free choice" of the applicable company law. Similar questions can be asked in the insolvency law field.

\section{Abusing Freedom of Establishment by COMI Shifts}

As a starting point, it is not doubtful that if a company shifts its COMI from one Member State to another, this activity is protected under the freedom of establishment. That is also true if the COMI shift is undertaken with an eye on the applicable insolvency regime. If a company moves its real seat or actual head office from Member State A into Member State B, this will always go hand in hand with a significant change in the regulatory environment affecting the company. A move that is motivated by a more attractive regulatory environment is commonplace. The decisiveness of the COMI for the applicable insolvency law reflects the consideration that it is at the COMI where the creditors are best protected. As a general principle, then, there is nothing wrong with COMI shifts undertaken with the new applicable insolvency regime in mind.

However, exceptional circumstances are conceivable in which a COMI shift might be judged to amount to an abuse of freedom of establishment. If, e.g., such a shift is undertaken exclusively in order to harm a (legal) person's creditors as a group, it might be considered abusive. For all practical purposes, 
however, nothing turns on this judgment. As we shall see in Section V, the EIR can and does take a more "critical" stance with respect to COMI shifts. In order to achieve a higher level of creditor protection, COMI shifts are controlled - on the basis of the abuse of law concept - in a greater variety of circumstances. Hence, if the EIR is abused, this does not imply that there is a simultaneous abuse of freedom of establishment. Conversely, in all cases in which one could argue that freedom of establishment is abused, there will also be an abuse of the EIR.

\section{Free Choice of the Applicable Insolvency Regime}

A more interesting question regarding the influence of freedom of establishment on the applicable insolvency regime is whether private actors might have a right to freely choose that regime. After all, this is the state of affairs in company law: an entrepreneur who is based in Member State A can freely choose to incorporate in Member State B to conduct his business activities even though there is no material connection with Member State B apart from the formal act of the registration of the company. In essence, this amounts to a right to freely choose the company law regime applicable to a particular business. Hence, it is a sensible question to ask whether companies also have a right under Arts 43 and 48 EC Treaty to freely choose the insolvency law regime applicable in case of financial distress. This question seems all the more relevant as the boundaries between company and insolvency law are blurry, especially with regard to creditor protection issues.

If, as a starting point, freedom of establishment protects COMI shifts, it is clear that there is a restriction on freedom of establishment if the company faces a new insolvency regime after a COMI shift. At the same time, the protection of workers and creditors are imperative requirements in the general interest that, in the ECJ's jurisprudence, can justify such restrictions. ${ }^{33}$ These requirements are affected most strongly at the debtor's COMI. Hence, the application of the insolvency law of the jurisdiction in which the COMI is located serves an imperative requirement in the general interest. Freedom of establishment, therefore, does not mandate a "free" choice of the applicable insolvency regime. ${ }^{34}$

34 See on this issue Eidenmüller (n 13) 446. Contrast Ringe (n 17) 27. However, Ringe does not sufficiently take into account the protection of workers and creditors in interpreting freedom of establishment and its reach. I agree that abuse of law can only be established on a case by case basis according to the ECJ. However, Member States are entitled to pass general laws in order to protect imperative requirements in the public interest (see only Inspire Art (n 2) para 133). 
We can conclude this section by stating that shifting the COMI of a company to another Member State is protected under the freedom of establishment and is in principle not abusive. However, freedom of establishment does not mandate a "free" choice of the applicable insolvency regime, i. e., companies do not enjoy a right to pick the applicable insolvency law that best suits their needs irrespective to where the company's real seat is located.

\section{$V$. Abusing the European Insolvency Regulation}

As the EIR is the legal framework for the administration of cross-border insolvencies in Europe, and as jurisdictional issues are dealt with by the EIR, abuse of law questions in the insolvency field arise primarily under the EIR. The phenomena to be explored further are COMI shifts. It has already been noted that abusing the EIR is an issue of real - not faked - COMI shifts (faked COMI shifts would be a fraud issue). COMI shifts are especially troublesome if they are not accompanied by a reincorporation and a change in the applicable company law. If a COMI shift is associated with a reincorporation under the tenth directive on cross-border mergers, the creditors of the participating companies receive protection under the applicable Member States' rules (see Art 4 para 2 of the directive). ${ }^{35}$ "Isolated" COMI shifts without a change in the applicable company law are problematic for another reason: if a company thereafter is restructured in the Member State where the new COMI is located, a discrepancy between the applicable company and insolvency law results. This creates frictions and increases bankruptcy costs. Hence, the focus of the following will be on such "isolated" COMI shifts without an associated change in the applicable company law. ${ }^{36}$

35 To be sure, a change in the applicable company law can be achieved without making use of the mechanism of the tenth directive. As an example, consider an English limited company that joins a German partnership as a limited partner. Thereafter, the general partner and all other limited partners of the German partnership withdraw from it. The consequence of this is that the English limited company succeeds to all assets and liabilities of the firm as the only remaining partner and the German partnership vanishes. Such mechanisms are sometimes used in practice as, e. g., in the Brochier case mentioned earlier in the text. If this is done, the creditor protection devices of the tenth directive obviously do not apply. However, this transaction only works if all shareholders agree on it.

36 Just take the case of a German GmbH or AG that tranfers its real seat and its COMI abroad: even under the real seat theory, it stays a German company (see Cartesio (n 2 above) paras 109 et seq on the real seat theory and Arts 43, 48 EC Treaty), as long as it moves to a country like the UK or Ireland that applies the incorporation theory (which will lead to German law being applicable as the law of the statutory seat). German 
The contractual means at the disposal of creditors to prevent COMI shifts are limited. Meanwhile, syndicated loan agreements sometimes contain clauses with which the debtor represents that its COMI is in a particular Member State. ${ }^{37}$ However, such a clause refers only to the status quo and does not prevent a COMI shift. More effective in this respect is a covenant that requires the debtor to seek the assent of the lenders with respect to a planned COMI shift. Failing to do so results in an acceleration of the underlying payment obligation. However, such a loan covenant is found only in economically significant lending transactions. For trade creditors, it is normally simply uneconomical to seek and draft detailed covenants to obtain an enhanced level of protection. For them, retention of title clauses are a much more common and sensible means of self-help. Moreover, "anti-COMI-covenants" certainly do not deter debtors that are determined to effectuate a COMI shift in order to benefit at the expense of their creditors. Hence, COMI shifts are a problem that creditors cannot solve on their own conclusively.

\section{Goals of the Regulation and Prerequisites for Abuse}

If the principal requirement for an abuse of law is that a particular legal provision is used contrary to its purpose, the main task with respect to abuse of law questions in the context of the EIR is to identify precisely the goals of the regulation. Two important goals are stated explicitly in the regulation's recitals. In recitals 2, 8, 16, 19 and 20, the efficient and effective administration of cross-border insolvencies is emphasised. That goal conforms to the aim of maximising the net assets to satisfy creditors' claims that was mentioned in Section II. Further, in recital 4 the EIR explicitly states that forum shopping should be prevented. This goal conforms to the economic aim of fostering the efficiency of credit contracts, which was also mentioned in Section II.

It is obvious that these two goals may conflict with each other. Under certain circumstances, an efficient and effective administration of a cross-border insolvency might require a change in the COMI. Imagine, e.g., the simultaneous financial distress of many members of a corporate group. In such a situation, all insolvency proceedings over all the assets of all members of the corporate group should be administered in the same jurisdiction and

corporate law only requires a statutory seat, not a real seat, in Germany (section 4a GmbHG and section $5 \mathrm{AktG}$ ).

37 A clause in a loan document on file with the author reads as follows: "For the purposes of 'The Council of the European Union Regulation No. 1346/2000 on Insolvency Proceedings', [the debtor's] centre of main interest (as that term is used in Article 3(1) of the Regulation) is situated in England and it has no 'establishment' (as that term is used in Article 2(h) of the Regulation) in any other jurisdiction.” 
possibly even by the same insolvency court and/or administrator. ${ }^{38}$ This way, it is much easier to coordinate the proceedings as opposed to a situation where different courts of different Member States and different insolvency administrators are in charge with respect to the various members of the corporate group. If, as a consequence, a COMI shift is undertaken with respect to some corporate group members, that will work against the goal of fostering the efficiency of credit contracts, however. Hence, the question that eventually must be answered is: which of the two goals of the EIR is more important?

In my view, it is the first goal. There are a number of arguments that support this position. First, the EIR has deliberately chosen a changeable criterion with respect to jurisdiction for main insolvency proceedings, namely the COMI. ${ }^{39}$ Hence, it is both difficult and probably not sensible to make the COMI "stickier" by interpreting it in a way that would make changes much more difficult. Second, the EIR does not establish a suspect period, i. e., it does not contain a rule to the effect that a former COMI remains decisive if the insolvency petition is filed shortly after a COMI shift. If such a suspect period existed in the EIR, it could be conceived as an "institutionalised anti-abuse rule". The absence of such a rule indicates that the prevention of forum shopping is not the paramount goal of the EIR. ${ }^{40}$ Third, preventing forum shopping by applying the abuse of law concept introduces legal uncertainty into the handling of jurisdictional issues, and that - from an economic perspective - translates into costs. Forth and finally, even though forum shopping is associated with undesirable economic effects, it is not the case that the insolvency regimes of the Member States are so different that one would have to fear that certain Member States might be attractive as an insolvency venue because they offer unique and extensive opportunities for the exploitation of certain creditors. Hence, preventing forum shopping is not the paramount goal of the EIR. The efficient and effective administration of a

38 H Eidenmüller, "Verfahrenskoordination bei Konzerninsolvenzen", (2005) 169 Zeitschrift für das gesamte Handels- und Wirtschaftsrecht 528, 537 et seq, 560 et seq; $\mathrm{H}$ Hirte, "Towards a Framework for the Regulation of Corporate Groups' Insolvencies”, (2008) 5 European Company and Financial Law Review 213, 218 et seq.

39 See also M-P Weller, "Die Verlegung des Center of Main Interest von Deutschland nach England”, (2008) Zeitschrift für Unternehmens- und Gesellschaftsrecht 835, 850.

40 Suspect periods of the kind described in the text are in place in Italy and Spain (cf Art 9 para 2 no 4 Legge Fallimentare and Art 10 no 1 Ley Concursal). In France, insolvency courts have apparently demanded that the debtor's COMI be in France for about half a year, see G Hölzle, "Wege in die Restschuldbefreiung und Schuldenerlass im Exil Oder: Lohnt die Flucht nach Frankreich wirklich?”, (2007) Zeitschrift für Verbraucher- und Privatinsolvenzrecht 1, 4. Insofar as these provisions are meant to be applied also to cross-border COMI shifts, they cannot be reconciled with Art 3 para 1 EIR, i. e., they violate the regulation and are to be disregarded. 
cross-border insolvency and thus maximising the net assets to satisfy creditors' claims is more important.

This has immediate consequences for the question under which circumstances a COMI shift undertaken to change the jurisdiction for main insolvency proceedings can be judged to be abusive. Everything turns on whether the COMI shift contributes to maximising the net assets available to satisfy creditors' claims. If it does, it surely cannot be considered abusive. If it does not, it can, at least in principle. Given that the effect on the debtor's net assets will be difficult to judge in many cases, abuse should be reserved for those where it is evident that this effect is not positive.

Even then, it will often not be easy to determine whether this criterion is fulfilled. Hence, other factors must be considered with respect to the motives driving the COMI shift. COMI shifts that evidently benefit either the debtor at the expense of its creditors or some creditors at the expense of others are suspicious. Such COMI shifts are driven by distributive considerations and not by the goal of maximising the net assets available to satisfy creditors' claims. If a COMI shift is evidently effected in order to enrich the person(s) initiating it at the expense of other stakeholders, the shift is abusive. Speaking very crudely, it all comes down to the question of whether a COMI shift is driven by considerations of efficiency (no abuse of law) or considerations of claiming value, i. e. distributive concerns (abuse of law).

To conclude this section one may state that COMI shifts that evidently do not contribute to maximising the debtor's net assets are abusive. This will be the case especially if a COMI shift is evidently only undertaken to benefit the debtor at the expense of its creditors or some creditors at the expense of others.

\section{COMI Shifts Before the Insolvency Petition}

COMI shifts can be undertaken before or after the insolvency petition. The focus of this section will be on the former case, whereas the next section will address the latter. A further distinction can be made between COMI shifts by companies and shifts that are undertaken by natural persons.

\section{a) Companies}

The application of the general principle developed in the last section to COMI shifts effectuated by companies before the insolvency petition can be neatly illustrated by two recent cases that were decided by German courts. The first 
case concerns an inward bound COMI shift ${ }^{41}$ and the second one an outward bound COMI shift. ${ }^{42}$ In the first case, the "PIN group" holding company shifted its COMI from Luxembourg to Cologne for restructuring purposes. The PIN group is a German enterprise with most of the operating companies having their registered office in Germany. The group is engaged in the mail delivery business. The holding company apparently had its registered office and its COMI in Luxembourg for financial reasons. The COMI shift occurred on the eve of insolvency, and the purpose of it was to facilitate the restructuring of the group by coordinating the proceedings over all of the group's subsidiary companies. This was much easier with all proceedings being controlled by the same insolvency court.

The Local Court ("Amtsgericht") in Cologne held that even though the COMI shift occurred in the immediate vicinity of the insolvency petition, it was not abusive because it served the restructuring objective and was undertaken for that purpose. In this case, the COMI shift clearly was in the interests of all creditors of the PIN group companies because it made the effective coordination of the proceedings easier and thus helped maximise the net assets available to satisfy the creditors' claims. Hence, the COMI shift was in conformity with the main goal of the EIR.

In the second case, the debtor company shifted its COMI from Germany to Spain on the eve of a bankruptcy petition by one of the (German) creditors in order to "bury" the company there. The company's owners apparently hoped that insolvency proceedings in Spain would not be initiated, or at least not opened, so that the company could be dissolved outside such proceedings and without court supervision. The company effectuated the COMI shift by appointing a new manager who was based in Spain.

The German Federal Court of Justice decided that the COMI shift was abusive and therefore would not be recognised. Clearly the shift was not triggered by the goal of maximising the net assets available to satisfy the creditors' claims. Its only purpose was to transfer value from the creditors to the debtor and its owners, i. e. to enrich the latter at the expense of the former. Hence, the Court was correct in finding that the COMI shift was abusive. In fact, in this case there was not only an abuse of Art 3 para $1 \mathrm{EIR}$, but also an abuse of the freedom of establishment guaranteed by the EC Treaty. It is clearly not the purpose of Arts 43 and 48 to afford protection to a new primary

41 Local Court (“Amtsgericht”) Cologne, Resolution of 19 February 2008 (73 IE 1/08), [2008] Zeitschrift für Wirtschaftsrecht 423.

42 Federal Court of Justice ("Bundesgerichtshof”), Resolution of 13 December 2007 (IX ZB 238/06), [2008] Entscheidungen zum Wirtschaftsrecht 181. 
establishment in another Member State which is set up only to prevent the enforcement of creditor rights.

If - as in this case - an abuse of law with respect to a COMI shift prior to the insolvency petition can be ascertained, the "old" COMI stays decisive on a purposeful reading of the EIR. Jurisdiction to open main insolvency proceedings thus remains with the courts of the Member State in which the COMI was located before the abusive shift.

What if months or even years pass after a COMI shift before an insolvency petition is filed? Denying jurisdiction at the new COMI is only justified if, on the facts of the particular case, the move and the insolvency petition are part of a strategic maneuver: the user establishes the formal elements of a legal provision and objectively makes use of it for a purpose that does not conform to its rationale. A judgment is required to ascertain this. However, that should not be too difficult in most situations in which the issue of abuse of law comes up at all: situations where the COMI shift and the insolvency petition appear to be part of a plan carried out in a short time-span, as in the case decided by the Federal Court of Justice.

The two cases discussed in this section highlight the general principle developed in the previous one: COMI shifts undertaken before the insolvency petition in order to maximise restructuring value are not abusive; COMI shifts undertaken to transfer value from the creditors to the debtor do not contribute to maximising the debtor's net assets and are abusive.

\section{b) Natural Persons}

COMI shifts before the insolvency petition can also occur with respect to natural persons. The COMI of individual entrepreneurs corresponds to their professional domicile. A consumer's COMI coincides with his or her habitual residence. Both criteria can be changed quite easily and quickly: the individual simply has to move to another country with the intent to stay there permanently. As in the previous section, the focus here will again be on real as opposed to faked - COMI shifts. There are various service providers who offer "professional" help to those who wish to establish themselves in another Member State. ${ }^{43}$ France in particular has become very popular lately as a destination for forum shoppers. This may have something to do with its agreeable living conditions. In the insolvency context, however, another factor certainly is much more important: the discharge regime in operation under French insolvency law.

Most jurisdictions worldwide give natural persons an opportunity to obtain a discharge from their debts by means of going through insolvency proceedings.

43 See, e.g., the following websites: http://www.frankreich-insolvenz.com; http:// www.sda-europe.de; http://www.bruckmann-partner.com. 
In Germany, e.g., such discharge can be obtained after a period of six years. Within that time, disposable income of the insolvent person above a certain retainable threshold is made available for the satisfaction of the creditors via a trustee. $^{44}$ The system in France, particularly in the départements of HautRhin, Bas-Rhin and Moselle, is much less rigid. In principle, a discharge is the immediate consequence of the ending of insolvency proceedings over the assets of a natural person. ${ }^{45}$ Given that such proceedings are handled within months and normally do not last longer than approximately a year, ${ }^{46}$ a discharge can be obtained in a much shorter time than in Germany.

The overall economic effects of shorter discharge periods are unclear. ${ }^{47}$ On the one hand, shorter discharge periods stimulate entrepreneurship, which is a positive economic effect. Also, such shorter periods contribute to preserving human capital because individuals are less prone to seek revenues in the shadow economy and more inclined to utilise and develop their talents "officially". On the other hand, the prospect of shorter discharge periods may encourage entrepreneurs to engage in excessive risk-taking and/or unprofessional management, which is a negative effect. Whether the positive effects outweigh the negative ones on an empirical level is an open question.

However, with respect to applying the general principle developed in Section $\mathrm{V} 1$, the first two effects are irrelevant: the individual in question now is in financial distress, and any ex ante effects that might have been at work long before the onset of the crisis now no longer play a role. The only relevant effect now is the third one, the preservation of human capital. However, that effect clearly does not contribute to "enlarging the pie" for the benefit of the creditors but is predominantly if not exclusively of advantage to the debtor. If that were otherwise, it would be hard to explain why creditors should forcefully object to a COMI shift of natural persons before the insolvency petition, which is what they regularly and unanimously do in practice.

Hence, a COMI shift effectuated by a natural person before an insolvency petition in order to obtain a more favourable discharge regime evidently is not in the interests of that person's creditors. It does not contribute to maximising

44 See sections 286 et seq of the German Insolvency Code ("InsO").

45 Cf Art L 622-32 and L 628-1 Code de Commerce. The insolvency law applicable in the above-mentioned regions differs from general French insolvency law so that the "Code de Commerce" is also applicable to natural persons that do not run a business.

46 See, e.g., G Hölzle (n 40) 5.

47 Cf. TH Jackson, "The Fresh Start Policy in Bankruptcy Law”, (1985) 98 Harvard Law Review 1393; BE Adler, E Polak and A Schwartz, "Regulating Consumer Bankruptcy: A Theoretical Inquiry”, (2000) 29 Journal of Legal Studies 585; J Armour and D Cumming, "Bankruptcy Law and Entrepreneurship", (2008) 10 American Law and Economics Review 303. 
the net assets to satisfy creditors' claims. It thus is abusive. On the other hand, a COMI shift undertaken by a natural person before an insolvency petition for reasons unrelated to the imminent insolvency situation is unobjectionable.

A distinction between these two scenarios can be made only on the basis of the fact pattern of the particular case. This pattern is relevant for judging whether the COMI (habitual residence) was shifted at all, and if so, whether the shift was abusive. A pertinent factor is the timing of the move: how close to the insolvency petition did it take place? And for how long after the insolvency petition was the new COMI maintained? Another relevant factor is whether the individual in question sought and/or found a new occupation/employment in the Member State into which he or she immigrated. Further, one has to consider whether assets have been shifted into the new Member State or not. One also must look at plausible other economic benefits that might have motivated the move (tax, health care, living expenses, etc). ${ }^{48}$ Finally, the magnitude of differences in the discharge provisions of the old and the new insolvency jurisdiction may play a role. Based on all these and possibly other factors surrounding the specific scenario, it must be determined whether the COMI was actually shifted at all, and if it was, whether the shift was effectuated primarily in order to obtain a more favourable discharge regime. If the habitual residence of the individual in question was not changed, or if a change was made predominantly to benefit from laxer discharge provisions, the "old" COMI still governs jurisdictional issues.

\section{COMI Shifts After the Insolvency Petition}

COMI shifts not only occur before an insolvency petition. It is also conceivable, and in fact quite practical, that a natural person or a company shifts its COMI after an insolvency petition has already been filed. In this context, the Staubitz-Schreiber decision of the ECJ is of great importance. In this case, Susanne Staubitz-Schreiber moved to Spain after an insolvency petition had been filed in Germany. The question thus had to be decided whether this move had the consequence that the competent German court lost jurisdiction for main insolvency proceedings over the assets of StaubitzSchreiber. Ultimately, the German Federal Court of Justice referred the case to the ECJ.

48 See the factors listed in Federal Court of Justice ("Bundesgerichtshof”), Resolution of 18 September 2001 (IX ZB 51/00), [2002] Neue Juristische Wochenschrift, 960, 961 et seq. 
The ECJ ruled ${ }^{49}$ that the COMI at the time of the insolvency petition was decisive. It held that acknowledging the COMI shift would go against the goals of the EIR: it would invite forum shopping, make it more difficult for the creditors to assess credit risks, and possibly force them to "chase" the debtor around Europe; the debtor would otherwise be able to play "cat and mouse" with his creditors by moving from one Member State to another. Moreover, acknowledging the validity of the COMI shift would, in the Court's opinion, be incompatible with the powers of a provisional administrator already appointed after the first insolvency petition to seek protection under Art 38 EIR.

Most of the arguments put forward by the ECJ to support its decision apply equally to COMI shifts that occur before an insolvency petition. However, as we have already seen in the previous sections, such COMI shifts may be driven by unobjectionable purposes and cannot always be characterised as abusive. Hence, some other factor must be present that could tip the balance in favour of the ECJ's holding that COMI shifts undertaken after an insolvency petition should never be acknowledged. Indeed, one such other factor is present: if one were to acknowledge a COMI shift after an insolvency petition has already been filed, insolvency proceedings would be much less efficient. Once an insolvency petition is filed, costs will normally immediately be sunk in the first proceedings. A provisional administrator will usually be appointed, temporary measures be taken, etc. All these measures would be thwarted if a COMI shift after the petition resulted in courts of another Member State acquiring jurisdiction for main insolvency proceedings. Hence, the ECJ correctly held that such jurisdictional issues should always be governed by the COMI at the time of the first insolvency petition.

This holding is also in line with the wide concept of the ECJ in Eurofood as to the "opening" of insolvency proceedings. In Eurofood the Court held that "... a decision to open insolvency proceedings ... [is] a decision ... based on the debtor's insolvency ... that ... involves divestment of the debtor and the appointment of a liquidator [including a provisional liquidator] referred to in Annex $\mathrm{C}$ to the Regulation." ${ }^{50}$ Based on that concept, the opening decision will often coincide with the decision to appoint a provisional liquidator, ${ }^{51}$ and this decision in practice is usually taken immediately after an insolvency petition has been filed. However, if insolvency proceedings have actually been

49 See Susanne Staubitz-Schreiber (n 6) paras 21-29.

50 Eurofood (n 7) para 54.

51 For an example, see Appellate Court (“Oberlandesgericht”) Innsbruck, Resolution of 8 July 2008 (1 R 176/08d), [2008] Neue Zeitschrift für das Recht der Insolvenz und Sanierung 700 with a comment by P Mankowski. 
opened in one Member State, that opening decision is to be recognised in all other Member States and a COMI shift would be irrelevant anyway.

We can conclude that whereas COMI shifts before an insolvency petition warrant a differentiated analysis, shifts after an insolvency petition are not to be acknowledged jurisdictionally under the EIR. The ECJ has correctly held that the COMI is "frozen" at the time of the insolvency petition. COMI shifts that occur after that point in time do not influence the allocation of jurisdictional powers between the Member States under the EIR.

\section{Abuse by Member States / Courts}

When discussing the general elements of the abuse of law concept, it has already been mentioned that not only private actors but also public entities (authorities) might be those that abuse insolvency provisions. I would now like to return to this point by discussing two examples in which it is the Member States or their courts that arguably are the ones to engage in abusive conduct. The first example relates to changes in procedures listed in Annex A of the EIR and the second to the "mind of management" theory adopted by some English courts to determine the COMI of a company.

The EIR applies only to proceedings that presuppose the insolvency of the debtor. That is quite clear from Art 1 para 1 and recital 10 of the regulation. For reasons of legal certainty, Annex A contains a conclusive and decisive list of proceedings that are governed by the rules of the EIR. ${ }^{52}$ One need not, and must not, go back to the general rule in Art 1 EIR to determine whether the regulation applies. Rather, a look at Annex A suffices.

Now suppose that Member State X changes proceedings listed in Annex A in such a way that, in the future, it will include restructurings that do not presuppose the insolvency of the debtor. Member State X does that in order to become Europe's leading restructuring venue. Arguably, exactly this has happened with the new English administration procedure introduced by the Enterprise Act in 2002. Since then, holders of a "qualified floating charge"53 can apply to the court for an administration order, and the court is empowered to make the order without the need to be satisfied that the company is or is likely to become insolvent (para 35(2)(a) Schedule B1 Insolvency Act 1986). ${ }^{54}$

52 On this see H Eidenmüller, "Europäische Verordnung über Insolvenzverfahren und zukünftiges deutsches internationales Insolvenzrecht”, (2001) Praxis des Internationalen Privat- und Verfahrensrechts 2, 4.

53 Para 14(2) Schedule B1 Insolvency Act 1986.

54 See also Fletcher (n 12) 139. 
It is true, however, that para 35(2)(b) Schedule B1 Insolvency Act 1986 requires the court to be satisfied that the owner of the qualified floating charge could appoint an administrator under para 14. According to para 16, an administrator may not be appointed under para 14 while a floating charge on which the appointment relies is not enforceable. A charge is not enforceable unless the debtor has failed to pay the underlying debt which it secures. Under English law, cash flow insolvency is established by a single unsatisfied demand for payment of an undisputed debt. ${ }^{55}$ Hence, in case of an undisputed debt, an insolvency according to Art 1 para 1 EIR seems to be present. However, even under English law insolvency is not a prerequisite if the claim of the holder of the charge has been disputed (which at least is conceivable). In addition, it is very doubtful whether the English definition of cash flow insolvency conforms to Art 1 para 1 EIR. The EIR does not define the term 'insolvency'. Nonetheless, it is clear that it only wants to deal with procedures that apply to companies in a financial crisis that threatens their existence. ${ }^{56}$ Insofar, the term 'insolvency' has an autonomous meaning that must be respected by the national legislators. An existencethreatening financial crisis can probably not be assumed in case of a single unsatisfied demand for payment of an undisputed debt. Be that as it may: irrespective of the position of English law on that matter, the problem of 'insolvency proceedings without insolvency' can at least be posed on a theoretical level.

In evaluating this case from an abuse of law perspective, one cannot stop at the primary purpose of Art 1 and Annex A of the regulation, which is to achieve legal certainty. Rather, one has to look at further (secondary) purposes and ask whether the person or entity relying on a particular legal position does so in contradiction to these (secondary) aims. On that basis, it seems clear that a Member State effecting a change as described above, abuses its powers under the EIR. It includes proceedings in the scope of the EIR to which the regulation explicitly does not want to be applied. That surely will increase the number of COMI shifts on the eve of insolvency and, as a consequence, forum shopping.

It is difficult to ascertain the consequences if a court of Member State $\mathrm{X}$ nonetheless opened "insolvency proceedings" under these circumstances. Before the opening decision, the court must check whether the proceedings would be carried within the reach of the EIR. Otherwise, the international jurisdiction of the court would not depend on Art 3 para 1 EIR. If the court determines that, because of the abuse just discussed, the EIR is not applicable, it must nevertheless open the proceedings on the basis of the national laws of Member State X. The sanction then comes with the reaction of the courts of other Member States: they would not need to recognise the proceedings as main insolvency proceedings under the EIR.

Another example of a potential abuse of the EIR by public entities, the "mind of management" theory, was in essence adopted early on by some English courts to determine the COMI of a company. The theory was developed

55 Cornhill Insurance plc v Improvement Services Ltd [1986] BCLC 26.

56 Virgòs/Schmit (n 8) 49. 
especially with respect to insolvency cases in the context of corporate groups. The idea behind it was that one could establish an identical COMI for all members of the corporate group at the location where the holding company was based: the mind of management of the subsidiaries was alleged to be with the mind of management of the holding company. ${ }^{57}$ In the Daisytek and Rover cases, lip service was paid by English courts to the ascertainability criterion of the EIR. However, as a matter of fact, these courts still applied the "mind of management" theory in basing their judgments mostly on internal factors between the companies that were not (easily) noticeable for outside creditors. ${ }^{58}$

Whilst the attempt to coordinate multiple proceedings by giving one single court jurisdiction over them is laudable, the "mind of management" theory clearly violates the ascertainability criterion stated in recital 13 of the regulation. To be sure, maximising the net assets available for distribution to the creditors is the paramount goal of the EIR. Nevertheless, in pursuing this objective one is bound to the COMI criterion stipulated by the EIR. The "mind of management" theory by far overstretches the interpretative leeway given by Art 3 para 1 EIR.

If one finds this to be abusive, as I think one should, the opening decision nevertheless stays effective. Being an official promulgation of a public entity, it cannot qualify as non-existent even if it is based on an abusive reading of the EIR. However, it is of course subject to being reversed on appeal by a superior court.

\section{Reforming the European Insolvency Regulation}

In concluding this article, it seems worthwhile to explore whether the EIR could be amended so that the current problems with respect to forum shopping would be solved and at the same time the need to resort to the abuse of law concept eliminated or at least diminished. Even though the debate on regulatory competition in insolvency law in Europe is still unresolved on an empirical level, it is clear that forum shopping on the basis of the COMI concept creates certain significant problems: it is associated with discrepancies between the applicable company and insolvency law and thus high bankruptcy costs, and it is also associated with possible detrimental effects on non-

57 Cf. R Leithaus, "Veranstaltung zu grenzüberschreitenden Insolvenzen in der Insolvenzpraxis in Köln", (2004) Neue Zeitschrift für das Recht der Insolvenz und Sanierung 194, 195 (reporting the view taken by S Taylor at a conference in Cologne on February 6, 2004).

58 Daisytek-ISA Ltd. [2003] BCC 562; MG Rover Deutschland GmbH [2005] EWHC 874 (Ch). 
adjusting creditors (see Section II). The abuse of law concept helps to ameliorate these problems, but it is only of limited help. It requires a case by case approach and thus creates legal uncertainty. Legal uncertainty, however, translates into economic costs.

A different approach would be to tie insolvency proceedings under the EIR to the registered office of a company in financial distress. ${ }^{59}$ This proposal comes down to turning the rule that a company's COMI conforms to its registered office from a refutable into an irrefutable presumption. Adoption of this proposal by the European legislator would improve matters compared to the status quo in various respects. First, in an insolvency situation company law and insolvency law would always go hand in hand. A company would be put into insolvency proceedings in the Member State in which it has its registered office. These proceedings would be governed by the insolvency laws of that Member State, and the company law of that Member State would - on the basis of the incorporation theory - govern matters of company law. Hence, the frictions and bankruptcy costs associated with "isolated" COMI shifts under the current regime could be avoided. ${ }^{60}$ Second, the proposal has advantages with respect to creditor protection. If a company wished to change the bankruptcy venue with respect to main insolvency proceedings, it would have to transfer its registered office. As we have already seen, this can be accomplished using the mechanism of the tenth directive. Such a reincorporation involves conforming to the creditor protection rules established by the laws of the affected Member States. ${ }^{61}$

Would it be advisable to combine the proposal made here with a suspect period such that not the actual registered office is decisive with respect to the opening of main insolvency proceedings, but the registered office at some earlier point in time, e.g. a few months or a year before the insolvency petition? We find such a suspect period in some European jurisdictions, ${ }^{62}$ and also under US law (see 28 USC $\$ 1408$ ). Although arguments can be put forward in favour of it, especially its deterrent effect on late-minute forum

59 See Eidenmüller (n 13) 438 et seq; J Armour, "Who Should Make Corporate Law? EC Legislation versus Regulatory Competition”, (2005) 58 Current Legal Problems 369.

60 This is also the decisive advantage of this approach compared to Ringe's suggestion according to which companies would be put into insolvency proceedings at their COMI, but with the law of the incorporating Member State as the governing insolvency law (cf Ringe (n 17) 28). The consequence would be that courts would have to apply foreign insolvency provisions with respect to their actual administration of an insolvency case. This is clearly not workable.

61 To be sure, under certain circumstances reincorporations may be achieved without using the framework of the tenth directive, see n 35 . However, this cannot regularly be done.

62 See $n 40$. 
shoppers and its clear-cut character (legal certainty), the length of such a suspect period is always arbitrary. Further, it prevents certain sensible late reincorporations. As an example, consider again the case of the Luxembourg holding company that was moved to Germany on the eve of bankruptcy. Finally, creditors are protected under the mechanisms of the tenth directive. Hence, I do not think that a suspect period with respect to changes in the registered office of a company on the eve of bankruptcy should be put into the EIR.

The proposal just discussed applies to companies and not to natural persons. Only companies necessarily have a registered office (natural persons that are not running a sole proprietorship do not), and only companies are potentially subject to the mechanisms of the tenth directive on cross-border mergers. With respect to natural persons, there is probably no good alternative to retaining the status quo, i. e. to look for the habitual residence as criterion for international jurisdiction with respect to main insolvency proceedings. At the same time, it is clear that the problems discussed in Section V $2 \mathrm{~b}$ regarding forum shopping are serious and require a convincing solution. As opposed to the case of companies, relocations on the eve of insolvency are rarely if ever desirable from the creditors' perspective in the case of natural persons. Also, the creditor protection provisions under the tenth directive do not apply to such persons. Therefore, a suspect period with respect to the habitual residence and, as a consequence, international jurisdiction to open main insolvency proceedings is the only available remedy. The EIR could stipulate, e.g., that the habitual residence six months before the insolvency petition is decisive.

To conclude, there are ways to improve the legislative framework of the EIR to reduce the negative effects of forum shopping on the eve of bankruptcy and render the need to employ the abuse of law concept to correct undesirable COMI shifts less pressing. For companies, the COMI should be replaced by the registered office as the only and decisive criterion with respect to international jurisdiction to open main insolvency proceedings. For natural persons, the habitual residence should be the relevant criterion, but it should be subject to a suspect period of a few months before the insolvency petition.

\section{Summary and Conclusion}

Questions of abuse of law in the context of insolvency law are closely linked to the debate about forum shopping on the eve of bankruptcy and regulatory competition between the Member States of the European Union in the insolvency field. It has been shown that the abuse of law concept can play a role in that it can put a check on undesirable forms of forum shopping. At the 
same time, legislative reform would provide a better solution: the European Insolvency Regulation (EIR) could and should be amended to the effect that it is not the 'Centre of Main Interests' (COMI) but the registered office of a company that is decisive with respect to international jurisdiction to open main insolvency proceedings. The main findings of this article can be summarised as follows:

1. Forum shopping in the insolvency field has both positive and negative economic effects. It may lead to the selection of efficient restructuring procedures and, in a group insolvency context, it may facilitate the coordination of multiple proceedings (which is good). It may also lead to discrepancies between the applicable company and insolvency law, reduce the efficiency of credit contracts and be done at the cost of involuntary or other "non-adjusting" creditors (which is bad). There is no conclusive empirical evidence on the overall economic effects of forum shopping in the insolvency field.

2. Abuse of law is a doctrinal concept on the scope of a legal position. Its main element is use of law contrary to its purpose. A specific "abuse intention" is not necessary. As an interpretative concept, abuse of law is a European concept insofar as the interpretation of a European legal provision is at issue. If a particular legal provision is abused, that provision cannot be relied upon by the (ab)user. Whoever wishes to rely on a particular legal provision is capable of potentially abusing it. Hence, not only private actors but also public entities might be challenged with abuse in a particular case (even though abuse by private actors surely is the much more common phenomenon).

3. Shifting the COMI from one Member State to another by a natural person or a company is protected under the freedom of establishment guaranteed by the EC Treaty and is in general not abusive. However, COMI shifts that evidently do not contribute to maximising the debtor's net assets for the creditors' benefit are abusive. COMI shifts that evidently benefit either the debtor at the expense of its creditors or some creditors at the expense of others are suspicious and fall into the category of abusive shifts: they are driven by distributive and not by efficiency concerns. As a consequence, COMI shifts by companies on the eve of bankruptcy that are undertaken in order to maximise restructuring value are not abusive; COMI shifts undertaken in order to enrich the debtor at the expense of its creditors are abusive, as are shifts in order to enrich certain creditors at the expense of others. COMI shifts by natural persons on the eve of bankruptcy effectuated to obtain a more favourable discharge regime are abusive.

4. The COMI of a company or natural person is "frozen" at the time of the insolvency petition. As a consequence, COMI shifts that occur after the 
insolvency petition have no effect on the international jurisdiction of a court to open main insolvency proceedings under the EIR.

5. The negative effects of forum shopping on the eve of bankruptcy should be addressed by a change in the legislative framework of the EIR. With respect to companies, COMI should be replaced by the registered office. In the future, only the registered office should be decisive with respect to the international jurisdiction to open main insolvency proceedings. This solution is not available regarding natural persons. With respect to them, the habitual residence should be the relevant criterion, as is the case under the current framework. However, a suspect period should be added to that framework, so that the habitual residence a few months before the insolvency petition determines international jurisdiction. 